\title{
Educational Smart Technologies in the Educational Process
}

\author{
Irina G. Borisenko* and Daria N. Volodina* \\ Siberian Federal University \\ 79 Svobodny, Krasnoyarsk, 660041, Russia
}

Received 11.11.2014, received in revised form 22.12.2014, accepted 09.02.2015

The article considers innovative technologies in the educational process which are based on the competence approach in teaching engineering graphics. The authors argue that the use of modern information technologies, interactive e-learning courses in the students' autonomous work as well as the students' involvement in project activities motivate them to learning and result in autonomous work effectiveness.

Keywords: information education, problems of education, autonomous work, e-learning, innovative activity.

Research area: philosophy.

Introduction of educational standards to the system of Federal State Educational Standards of Higher Professional Education (FSES of HPE) and changes, related to the FSES $3+$ project, which base not only on the competence approach but also on the informatization of educational process, as well as constantly growing amount of knowledge the students are provided with, and introduction of new subjects, on the one hand, and decrease in in-class hours and a low level of school leavers' basic training, on the other hand, require the learning process time optimization. To improve teaching effectiveness a teacher's methodical activity aims at integrating content, methods and forms of education into a single complex primarily due to the increase of the autonomous work intensity (Borisenko 2011, Philipjeva 2013). Indeed, according to modern educational standards, a student should spend fifty or more per cent of his / her study hours on autonomous mastering of an academic subject.

Learning efficiency is greatly enhanced through modern educational smart technologies. E-courses in Siberian Federal University's informational learning system (e.sfu-kras.ru) can serve an example of such work (Fig. 1). E-course is a set of software, technical, educational and methodological means, ensuring the students' active individual learning.

Theoretical material, downloaded in sections in an interactive course, significantly facilitates the information search and, to some extent, prevents the students from relying upon the information on the Internet that might be of poor quality or sometimes harmful. An opportunity to view video lessons, use interactive glossary as

(C) Siberian Federal University. All rights reserved

* Corresponding author E-mail address: i.g.borisenko@yandex.ru, dar-volodina@yandex.ru 


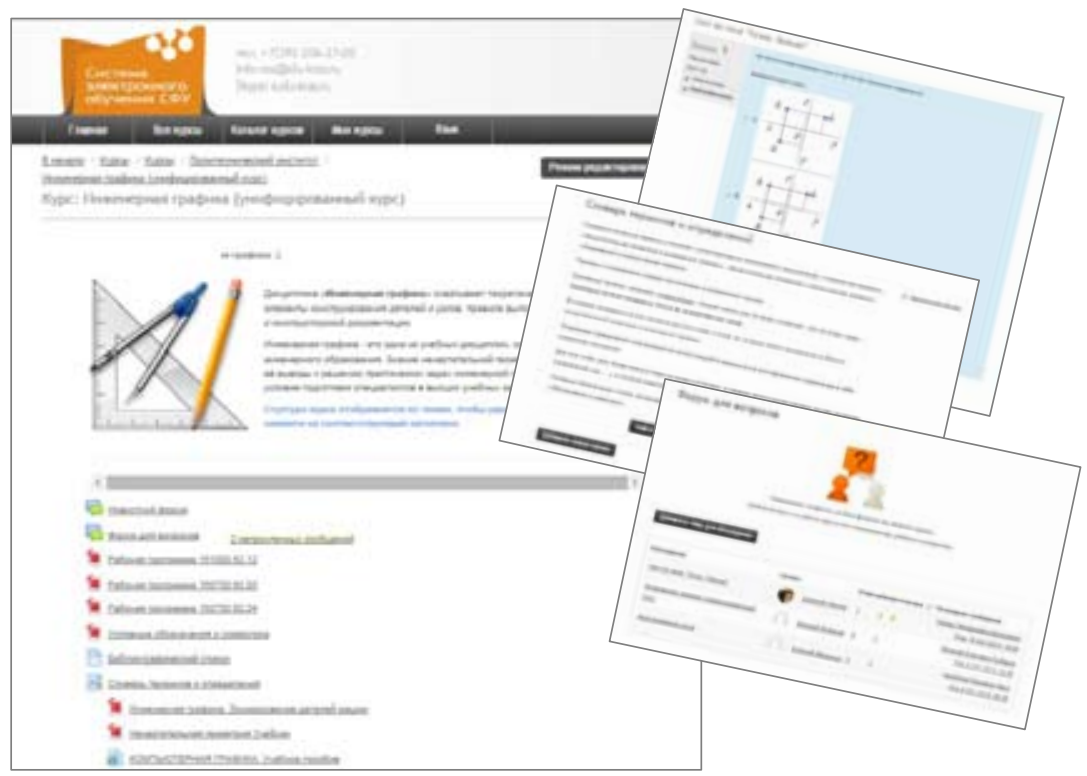

Fig. 1. SibFU informational learning system (e.sfu-kras.ru)

an additional source of educational information makes it possible to provide the students with vast amount of theoretical material. Sets of test items for each course section and assignments for practical work allow the students to start doing tasks at the time convenient for them as well as to promptly learn the marks for their theoretical knowledge and work done.

A set of software, technical, educational and methodological means, ensuring the students' active individual learning, is the following:

1. Access to theoretical material for autonomous mastering of new material and / or its revision in "online / offline" mode.

2. Option to present theoretical material in the form of a discipline ontology or a semantic textbook with intermediate testing of knowledge.

3. Assessment of autonomous work regarding the number of attempts the task has been done.

4. Rating the students on the basis of the points they get stimulates them to do the task again in order to get a higher score. It also results in the competition among the students.
5. Option for self-testing regardless the rating and the total score.

6. Communicative elements of the course help to overcome a clouding effect, repeatedly reread the message or redo the task (without time and class schedule limits), to think over/correct the answer.

Having transformed a traditional form of learning, new technologies make it easier for the students to grasp and understand difficult theoretical material. This leads to the students' higher cognitive activity. Video lessons, animation and slides (thematic presentations), incorporated in e-courses, improve the students' level of mastering the material (Borisenko 2011, 2014; Borisenko et al. 2014).

The advantages of engaging the elements of communication (forums, chats, messaging) with respect to 'student - student', 'student teacher' modes are the following: a student and a teacher can communicate in a comfortable environment and at the time convenient for them. Communication with other participants on the e-course forum results in a creative atmosphere 
and a dialogue between students as well as between students and teachers.

E-learning courses save the students' time spent on home assignments. Organizational and methodological support of an academic process, developed on the basis of distance learning technologies, keeps the students involved in learning. It facilitates their interaction with teachers, provides them with electronic teaching materials and access to the university's informational and educational network. The teacher has an opportunity to monitor the learning process and the level of mastering the material on any stage of learning, which results in the students' motivation to meet the deadlines set for the tasks to be done. Moreover, the students are allowed to do final exercises and tests, the scores for which are important for a final grade for the discipline, only in case they have done the tasks for autonomous work. The students must get a satisfactory mark for their autonomous work to get an access to reading the text of a final task or exercise. Each theme studied should be completed with a test which may cause the necessity to revise the theory. This leads to the students' individuality and creativity and shapes their cognitive activity.

Communication on the forum of an e-learning course favours an atmosphere of creativity and a dialogue. Communication on a particular subject between students and a teacher as well as between students develops interpersonal skills and collaboration, both being competencies which are extra to the professional ones.

Development of e-learning courses, modern methodological support, use of the latest technology, computers and other interactive media in teaching engineering graphics and other engineering disciplines make it possible to introduce active methods of teaching in order to improve its efficiency, develop the students' cognitive and creative activity, prepare them for independent professional activity. All this together contributes to the development of a future qualified specialist's or a bachelor's professional competences, meeting the requirements of actively developing economy and the society as a whole.

The students' results in e-learning courses are marked with considerable progress (for example, in 2013 the points for a final test were $15-20 \%$ higher compared to 2012 when this system wasn't introduced yet) while the level of their initial training in 2012 and 2013 was practically the same which is evidenced by the results of the entry test. The test was done by the same number of the students. They were asked to give anonymous answers to five questions: 1) What is the area of a circle? 2) What is the circumference? 3) What is the length of the arc of the circle? 4) How is the circumference divided into six equal parts with the compasses? 5) How is the perpendicular bisector restored to the line segment with the compasses (Borisenko et al. 2014)? The histogram (Fig. 2) shows the number of students who gave correct answers to the questions of the entry tests 2012 and 2013 mentioned above. The entry test involved the same number of students. The question about the length of the arc of the circle caused the greatest difficulty.

Comparative analysis of the students' performance in 2012, when they were not trained in the SibFU informational learning system (e.sfu-kras.ru), and in 2013, when they were trained in e-learning system, was based on the results of mastering such disciplines as Engineering Graphics, Descriptive Geometry and Engineering Graphics, Engineering and Computer Graphics (Fig. 3) during the semester. The histogram (Fig. 3) shows the number of students and their performance as per the check points in a 100-point rating system in the years 2012 and 2013. 
Numb er of students, giving the right answers

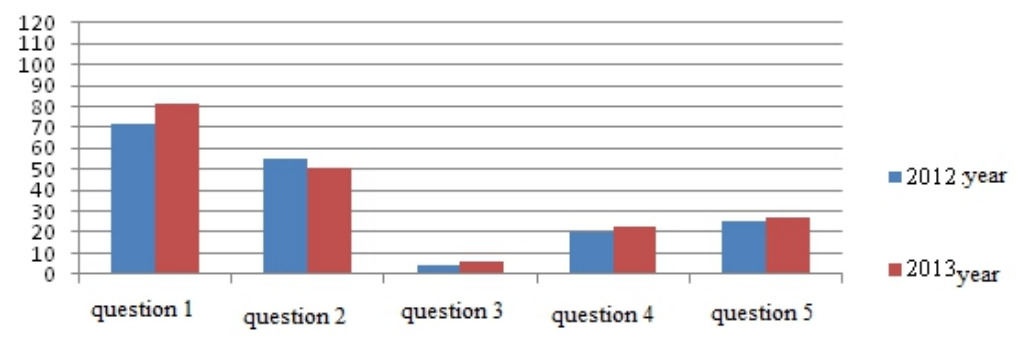

Fig. 2. Correct answers to specific questions

The students' performance as per their average score

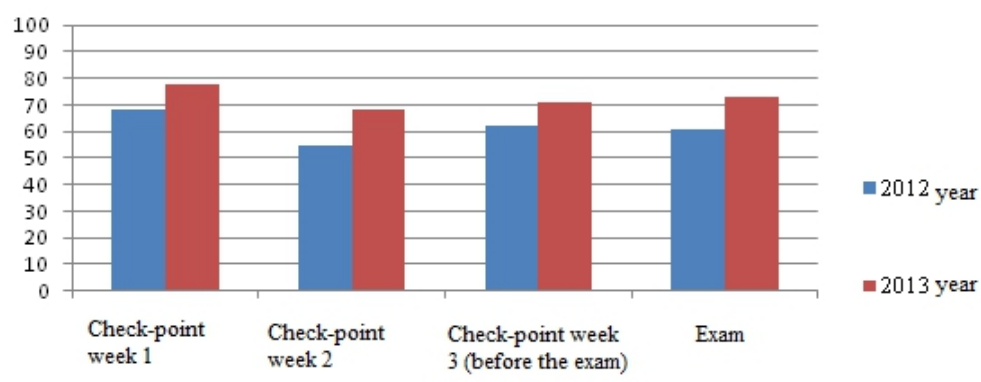

Fig. 3. The control group students' performance in winter-term exams

E-learning courses efficiency is in its maximum degree of individualization of the educational process, constant monitoring and effective management of the students. Elements and settings of a course motivate the students' autonomous mastering of a discipline. Theoretical material for self-study should be presented in various ways, convenient for a student, which engage several sensory canals. The students' individual learning styles determine the need for various ways and formats of presenting the material which is possible only in the informational learning space.

The context of educational informatization results in a cardinal change and significant increase of the teacher's role in the educational process organization. Whereas the modern system of education cannot be changed quickly, it is possible to improve it and, consequently, make the education more efficient in existing conditions.

Thus, we argue that new methodological approaches must be applied at all levels of the educational process by teachers and students, both autonomously and in-class. To improve the quality of education and solve the problems stated above the following measures are necessary:

Firstly, wide implementation and use of modern educational technologies will result in effective introduction of a systematic approach, which combines traditional and innovative methods of teaching students of all modes of learning, enabling the teacher to get a clear idea of each student's individual abilities and, thus, increase its efficiency in shaping a future specialist's personality. 
Secondly, the teacher must ensure organization, master the latest technologies the students freedom of self-actualization and innovative teaching methods and aim at through their creative growth. Therefore, he the improvement of their own professional and / she must be strongly motivated to search pedagogical competencies through innovation for the new in the educational process activity.

\section{References}

1. Borisenko I.G. (2011). Kompetentnostnyi podhod v prepodavanii nachertatel'noi geometrii $i$ inzhenernoi grafiki [Competence approach in teaching Descriptive Geometry and Engineering Graphics]. The Bulletin of KrasGAU, 12, 302-304.

2. Borisenko I.G., Golovina L.N., Volodina D.N. (2014). Problemy inzhenernogo obrazovaniia. Povyshenie effektivnosti samostoiatel'noi raboty [Engineering education problems. Improving independent work efficiency]. Vestnik of Irkutsk State Technical University, 1 (84), 171-175.

3. Borisenko I.G. (2014). Organizatsiia uchebnogo protsessa v interaktivnoi elektronnoi obrazovatel'noi srede [Organization of educational process into an interactive electronic learning environment]. Professional Education in Russia and Abroad, 2 (14), 119-123.

4. Philipjeva S.V. (2013). Ustanovlenie urovnei sformirovannosti obshchikh i professional'nykh kompetentsii obuchaiushchikhsia uchrezhdenii nachal'nogo i srednego professional'nogo obrazovaniia v sootvetstvii s FGOS novogo pokoleniia [General and professional competence assessment among the students of primary and secondary vocational training in accordance with the demands of federal state educational standards]. Professional Education in Russia and Abroad, 1, 60-67.

\section{Образовательные смарт-технологии}

в организации учебного процесса

И.Г. Борисенко, Д.Н. Володина

Сибирский федеральный университет

Россия, 660041, Красноярск, пр. Свободный, 79

Рассмотрены инновационные технологии в организации учебного процесса на основе компетентностного подхода при обучении инженерной графике. Авторы доказывают, что использование в самостоятельной работе современных информационных технологий, интерактивных электронных учебных курсов, вовлечение студентов в проектную деятельность повышают мотивачию к обучению и эффективность самостоятельной работы.

Ключевые слова: информационное образование, проблемы образования, самостоятельная работа, электронные курсы, инновационная деятельность.

Научная специиальность: 09.00.00 - философские науки. 